\title{
Performance of Soybean Seedlings Upon Nutrient Application by Seed Coating
}

\author{
Cassyo de Araújo Rufino ${ }^{1}$, Lizandro Ciciliano Tavares ${ }^{1}$, Pablo Martín-Ramos ${ }^{2 *}$, Jucilayne \\ Fernandes-Vieiraa ${ }^{1}$, José de Souza Abreu Júnior ${ }^{1}$, Fábio Júnior Araújo Silva ${ }^{1}$, Marciabela \\ Fernandes-Correa ${ }^{3}$, Jesús Martín-Gil ${ }^{1}$. \\ ${ }^{I}$ Federal University of Pelotas - Seed Science and Technology Laboratory, Pelotas, Rio Grande do Sul, Brazil; ${ }^{2}$ \\ Universidad de Zaragoza - Department of Agricultural and Environmental Sciences, EPSH Carretera de Cuarte, \\ $s / n$, Huesca, Spain; ${ }^{3}$ Universidad de Valladolid - Department of Agricultural and Forestry Engineering, Valladolid, \\ Castilla y León, Spain.
}

\begin{abstract}
The aim of this study was to evaluate the effect of different seed coatings consisting of various combinations of three nutrients (calcium, magnesium and silicon) on two soybean cultivars (BRS 243 RR and CD 233 RR). Dolomitic limestone and aluminum silicate were chosen as the nutrient sources. Leaf area, plant height, shoots dry matter, crop growth rate, relative growth rate and net assimilation rate were the studied variables, evincing that the seed coating that comprised calcium, magnesium and silicon led to better performance in terms of growth rates 30 days after emergence. Significant differences in the response to the seed coatings were also observed between the two studied soybean genotypes.
\end{abstract}

Key words: Glycine max (L.) Merr., growth rate, leaf area, micronutrients, seed treatment.

\footnotetext{
*Author for correspondence: pmr@unizar.es
} 


\section{INTRODUCTION}

In order to achieve higher economic returns and to enhance productivity, it is essential to improve the quality of seeds. Apart from research on seed production, harvest, processing, sampling, storage, distribution and testing, applied and basic research on seed genetics, seed biotechnology, seed treatment and seedling establishment have also been deemed as key to attain aforementioned goals. We hereby discuss the impact of one of those innovative management practices, aimed at a more efficient use of nutrients in Agriculture: their direct application to the seeds via a coating technique.

In the particular case of soybean seeds, the effect of several nutrients on seedling establishment and yield has been studied in the literature: phosphorus ${ }^{1,2}$, potassium ${ }^{3}$, zinc ${ }^{4}$, cobalt ${ }^{5}$ and molybdenum ${ }^{6}$. In the study presented herein, the impact of calcium, magnesium and silicon is studied for two soybean genotypes.

The use of dolomitic limestone, an abundant mineral resource, is one the most commonly used materials for the correction of soil acidity ${ }^{7}$. Apart from promoting the neutralization of $\mathrm{Al}^{3+}$, raising the $\mathrm{pH}$, it is also a well-known approach to correct calcium and magnesium deficiencies in soils, thus enabling the proliferation of roots, with positive effects on the growth of shoots. However, due to the low solubility and slow movement of dolomitic limestone across the soil profile, a uniform distribution and deep embodiment is needed prior to the deployment of areas for seeding ${ }^{8}$. Obtaining a high yield in commercial crops requires the correction of soil acidity in the topsoil, so that the roots can explore a larger volume, favoring the absorption of water and nutrients by the plant ${ }^{9}$. Since much of action of the dolomitic limestone is limited to $0-20 \mathrm{~cm}{ }^{10}$, there is a growing interest in soils and crops that can mitigate the negative effects of soil acidity on seed production.

The interrelationship between $\mathrm{Ca}^{2+}$ and $\mathrm{Mg}^{2+}$ ions in plant nutrition is related to their close chemical properties, such as ionic radius, valence, degree of hydration and mobility, which results in a competition for the adsorption sites in the soil and root uptake. Consequently, the presence of one can be detrimental for the adsorption and absorption of the other ${ }^{11}$.

On the other hand, silicon is the main component of silicates, which account for ca. $28 \%$ of the Earth's crust, and is present -in its free form or combined- as the dominant part of the solid fraction and also dissolved in the soil solution ${ }^{12}$. It is a beneficial element for the growth of several species of plants and contributes to the mitigation of factors that cause biotic and abiotic stress ${ }^{13}$. In fact, it has been deemed as a beneficial micronutrient fertilizer under Brazilian law ${ }^{14}$. The importance of fertilization with silicon is related to an increased productivity through several indirect actions, such as more erect leaves; reduced self-shading; more rigid structural tissues -thereby reducing lodging-; an increased tolerance to abiotic stress -e.g., reduction of the toxicity of $\mathrm{Fe}^{2+, 3+}, \mathrm{Mn}^{2+}, \mathrm{Al}^{3+}$ and $\mathrm{In}^{3+}-$; and a decrease in the incidence of diseases and pest attacks ${ }^{15,16}$.

In Brazil, Santos, Korndorfer ${ }^{17}$, working with increasing doses of Wollastonite $\left(\mathrm{CaSiO}_{3}\right)$, observed significant increases in rice productivity with the highest applied dose $\left(6000 \mathrm{~kg} \cdot \mathrm{ha}^{-1}\right)$. In a similar fashion, Pereira, Korndörfer ${ }^{18}$, working with calcium metasilicate on rice crops, in a quartzarenic neosoil, recorded increases in grain yield of up to $33 \mathrm{~g} \cdot$ pot $^{-1}$ for an equivalent $\mathrm{Si}$ dose of $500 \mathrm{~kg} \cdot \mathrm{ha}^{-1}$.

Soybean (Glycine max [L.] Merr.) is generally considered sensitive to acidity (mainly to high levels of $\mathrm{Al}$ or $\mathrm{Si}$ ) ${ }^{19}$, soil texture and flooding stress ${ }^{20}$. Addition of dolomitic limestone to clayed soils should increase the $\mathrm{Mg}: \mathrm{Si}$ ratio, thus increasing the soil $\mathrm{pH}$ (reducing acidity to $6.5 \pm 0.5$ ) and creating a better texture to improve surface drainage problems. Because the clayed composition of a soil can be referred to silicate, different patterns of silicate-dolomitic limestone have been assayed to 
explore their effect on developing soybean seeds (of BRS 243 RR and CD 233 RR cultivars) with a view to increasing crop productivity.

\section{MATERIAL AND METHODS}

The work presented herein was conducted at the Laboratory of Seed Analysis (LDAS) and at the greenhouse facilities of the Faculty of Agronomy Eliseu Maciel (FAEM) at the Universidade Federal de Pelotas, in the 2009/10 season.

Two soybean cultivars were assessed, namely BRS 243 RR and CD 233 RR, supplied by Seeds E. Orlando Roos \& Cia. Ltda. Both cultivars feature early maturity and determinate growth habit, and have germination rates close to $86 \%$.

Seeds were sown on $15^{\text {th }}$ November. Prior to sowing, the seeds had been coated with the following products: Maxim-XL ${ }^{\circledR}$ (fludioxonil + metalaxyl-M) fungicide, at a dose of $100 \mathrm{~mL}$ per $100 \mathrm{~kg}$ of seeds; Sepiret ${ }^{\circledR}$ polymer (which incorporates Corasem, Seed Gloss and Policlaro) at a dose of $250 \mathrm{~mL}$ per $100 \mathrm{~kg}$ of seed; and Gelfix $5^{\circledR}$ inoculant at a dose of $200 \mathrm{~mL}$ per $100 \mathrm{~kg}$ of seeds.

Three treatments based on calcium, magnesium and silicon were evaluated. The nutrient sources were dolomitic limestone $(\mathrm{CaO} 32 \%$ and $\mathrm{MgO} 16 \%$, with a reactivity of $73 \%$ and relative neutralizing value of $70 \%$ ) and kaolinite $\left(\mathrm{Al}_{2} \mathrm{Si}_{2} \mathrm{O}_{5}(\mathrm{OH})_{4}\right.$, produced by the chemical weathering of aluminum silicate minerals like feldspar, containing $77.9 \% \mathrm{SiO}_{2}$ and with $\mathrm{pH} 5.5$ ), both of which were applied at a dose of $50 \mathrm{~g}$ per $100 \mathrm{~kg}$ of seeds. For the two nutrient sources used in the experiment, the amount of nutrients present was calculated separately and expressed in grams: the $50 \mathrm{~g}$ of dolomitic limestone contained with 16 and 8 grams of calcium and magnesium, respectively, and the aluminum silicate had 39 grams of silicon. The seeds were coated according to the method described by Nunes ${ }^{21}$, which is a manual procedure, using polyethylene bags. The treatments consisted of the coating of the seeds of the two cultivars with the following combinations of nutrients: $\mathrm{T} 1(\mathrm{Ca}+\mathrm{Mg}$ $+\mathrm{Si}), \mathrm{T} 2(\mathrm{Ca}+\mathrm{Mg}), \mathrm{T} 3(\mathrm{Si})$ and $\mathrm{T} 4$ (control, no soil correction).

Seeds were sown in pots with a capacity of 15 liters, filled with approximately $13 \mathrm{~kg}$ of substrate. Soil had been collected from horizon A1 of a solodic eutrophic haplic planosol ${ }^{22}$ belonging to the Pelotas mapping unit. Its chemical characterization is summarized in Table 1. Fertilization was conducted according to CFQS RS/SC recommendations ${ }^{23}$, with fertilizers incorporation at the time of sowing. Irrigation was performed on a daily basis, according to the daily needs of the soybean plants. The experimental unit was represented by a bucket containing three plants, totaling 32 experimental units. 12 seeds per bucket were initially sown, out of which only the three plants per bucket that had a higher initial size were kept after a thinning. Experiments were conducted in triplicate, sampling one of those three plants after each of the three assessment periods, that is, 10, 20 and 30 days after emergence (DAE) to evaluate shoot dry-matter production and other growth parameters, detailed below.

Table 1. Chemical characterization of the soil: acidity, exchangeable cations, cation exchange capacity, macronutrients and micronutrients.

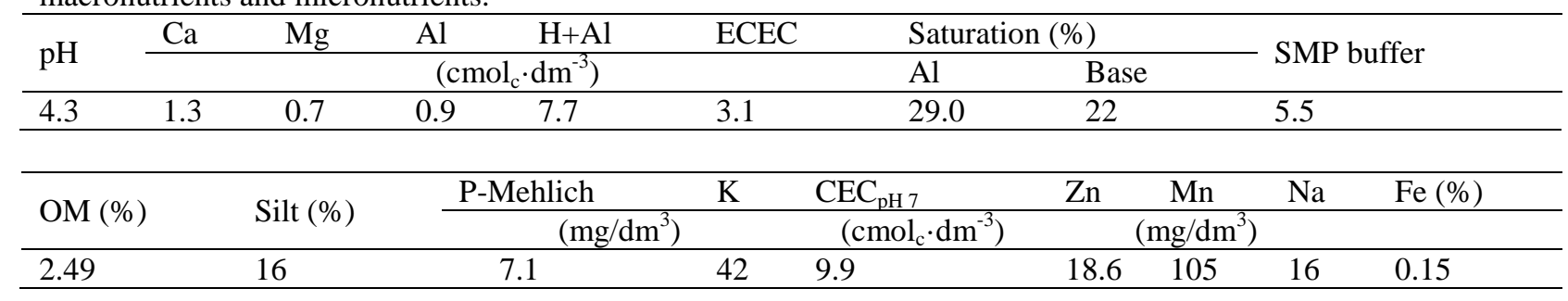


CEC: cation exchange capacity; ECEC: effective CEC; SMP: Shoemaker-McLean-Pratt buffer method; OM: organic matter; P-Mehlich: Mehlich-3 soil phosphorus test. $\mathrm{pH}$ in water 1:1. Exchangeable $\mathrm{Ca}, \mathrm{Mg}, \mathrm{Al}$ and $\mathrm{Mn}$ extracted with $\mathrm{KCl} 1 \mathrm{~mol} \cdot \mathrm{l}^{-1}$. Silt determined by densitometer method. OM determined by wet digestion. P, K, Na and $\mathrm{Zn}$ determined by Mehlich-method.

The following variables were considered: leaf area, plant height, shoots dry matter, crop growth rate, relative growth rate and net assimilation rate. Leaf area (LA) was measured using a LI-3100C Area Meter (LI-COR Ltd.). To determine the shoots dry weight (SDW), the aerial parts of the plants were cut at soil height and then placed in an oven at $60{ }^{\circ} \mathrm{C}$ until constant weight was attained -to determine dry biomass- and weighed on a precision analytical weighing balance. Plant height (PH) was measured from the ground surface, using a millimeter ruler and the result was expressed in centimeters $(\mathrm{cm})$.

Growth rates were calculated in agreement with the methodology described by Gardner, Pearce ${ }^{24}$ :crop growth rate $(\mathrm{CGR})=\left(D M_{2}-D M_{1}\right) /\left(t_{2}-t_{1}\right)$, expressed in $\mathrm{mg} \cdot$ plant $^{-1} \cdot \mathrm{day}^{-1} ;$ relative growth rate $(\mathrm{RGR})=\left(\ln D M_{2}-\ln D M_{1}\right) /\left(t_{2}-\right.$ $\left.t_{1}\right)$,expressed in $\mathrm{mg} \cdot \mathrm{g}^{-1} \cdot \mathrm{day}^{-1}$; net assimilation rate $(\mathrm{NAR})=\left[\left(D M_{2}-D M_{1}\right) /\left(t_{2}-\right.\right.$ $\left.\left.t_{1}\right)\right] \cdot\left[\left(\ln A F_{2}-\ln A F_{1}\right) /\left(A F_{2}-A F_{1}\right)\right]$, expressed in $\mathrm{mg} \cdot \mathrm{cm}^{-2} \cdot$ day $^{-1} . D M, t$ and $L A$ stand for dry matter, time and leaf area, respectively.

The experimental design consisted of randomized blocks in a $2 \times 4$ factorial scheme (two cultivars and four treatments), with four repetitions. Data were subjected to an ANOVA. Means were compared by Tukey's HSD test at 5\% significance level. All statistical analyses were conducted using Statistical Analysis System Version 2.0 for WinStat ${ }^{25}$.

\section{RESULTS}

Effect of the Treatments 10 Days after Emergence

Statistical differences between the two cultivars were found in terms of dry weight for both cultivars (see Table 2). In the case of CD 233 RR, all treatments had a negative impact, which was particularly remarkable for the silicon-based one (T3). Conversely, for BRS 243 RR, the dry weights were significantly higher for the treated seeds that for the control in all cases (T1, T2 and T3).

An analogous behavior was shown in terms leaf area, for which the seed coatings also had disparate effects on both cultivars: the application of seed coatings again had a negative impact on CD 233 RR (i.e., the best results were obtained for the control), whereas all treatments were beneficial to BRS $243 \mathrm{RR}$, in particular the one with $\mathrm{Ca}^{2+}+\mathrm{Mg}^{2+}$ (T2), which led to the highest leaf area $\left(135.4 \mathrm{~cm}^{2}\right)$.

In reference to plant height, the highest plant height for CD 233 RR cultivar was obtained for the control $(15.8 \mathrm{~cm})$ and all the seed coating treatments had a negative effect, while for BRS 243 RR the largest plant height corresponded to T1 treatment $(15.35 \mathrm{~cm})$.

\section{Effect of the Treatments 20 Days after Emergence}

In relation to the dry weight 20 days after emergence, it was found that the seed coatings had a remarkably negative impact on both cultivars (see Table 3 ). On the other hand, the behavior in terms of foliar area was dissimilar for the two cultivars under study: while seed coatings had a negative effect on CD $233 \mathrm{RR}$ in all cases (specially deleterious for T3), the application of T1 seed coating had a very positive impact on BRS $243 \mathrm{RR}\left(557 \mathrm{~cm}^{2}\right.$ for T1 vs. $425 \mathrm{~cm}^{2}$ for the control). T2 and T3 application was not favorable, but to a lesser extent than for CD $233 \mathrm{RR}$. 
With regard to the plant height variable, $\mathrm{T} 1$ treatment $(\mathrm{Ca}+\mathrm{Mg}+\mathrm{Si})$ had the most positive impact on both cultivars. On the other hand, for T2 and T3 treatments the response of the cultivars differed: while they were detrimental for CD $233 \mathrm{RR}$ (in particular T3), they were beneficial for BRS 243 RR (although in this later case there were no significant differences from a statistical point of view).

Table 2. Dry weight, leaf area and plant height of the soybean plants for the different seed coating treatments 10 days after emergence. All values are in average \pm standard deviation.

\begin{tabular}{|c|c|c|c|c|c|c|}
\hline \multirow{2}{*}{ Nutrient combinations } & & \multicolumn{5}{|l|}{ Dry weight $(\mathrm{g})$} \\
\hline & & \multicolumn{2}{|l|}{ BRS 243 RR } & CD 233 RR & \multicolumn{2}{|c|}{ Average } \\
\hline \multicolumn{2}{|l|}{$\mathrm{Ca}+\mathrm{Mg}+\mathrm{Si}$} & \multicolumn{2}{|l|}{$0.28 \pm 0.04 \mathrm{aA}$} & $0.22 \pm 0.05 \mathrm{aB}$ & \multicolumn{2}{|l|}{0.25} \\
\hline \multicolumn{2}{|l|}{$\mathrm{Ca}+\mathrm{Mg}$} & \multicolumn{2}{|l|}{$0.29 \pm 0.03 \mathrm{aA}$} & $0.25 \pm 0.02 \mathrm{aB}$ & \multicolumn{2}{|l|}{0.27} \\
\hline \multicolumn{2}{|l|}{$\mathrm{Si}$} & \multicolumn{2}{|l|}{$0.27 \pm 0.10 \mathrm{aA}$} & $0.15 \pm 0.01 \mathrm{bC}$ & \multicolumn{2}{|l|}{0.21} \\
\hline \multicolumn{2}{|l|}{ Control } & \multicolumn{2}{|l|}{$0.14 \pm 0.04 \mathrm{bB}$} & $0.34 \pm 0.02 \mathrm{aA}$ & \multicolumn{2}{|l|}{0.24} \\
\hline \multicolumn{2}{|l|}{ Average } & \multicolumn{2}{|l|}{0.24} & \multicolumn{3}{|l|}{0.24} \\
\hline \multicolumn{2}{|l|}{ Std. dev. } & \multicolumn{2}{|l|}{0.07} & \multicolumn{3}{|l|}{0.08} \\
\hline \multicolumn{2}{|l|}{$\mathrm{CV}$} & \multicolumn{2}{|l|}{$29.66 \%$} & \multicolumn{3}{|l|}{$32.47 \%$} \\
\hline \multirow{2}{*}{ Nutrient combinations } & Leaf area $\left(\mathrm{cm}^{2}\right)$ & \multicolumn{5}{|c|}{ Plant height $(\mathrm{cm})$} \\
\hline & BRS 243 RR & CD 233 RR & Average & BRS 243 RR & CD 233 RR & Average \\
\hline $\mathrm{Ca}+\mathrm{Mg}+\mathrm{Si}$ & $101.96 \pm 2.20 \mathrm{aB}$ & $93.27 \pm 4.52 \mathrm{aA}$ & 97.61 & $15.36 \pm 0.17 \mathrm{aA}$ & $13.40 \pm 0.50 \mathrm{aB}$ & 14.38 \\
\hline $\mathrm{Ca}+\mathrm{Mg}$ & $135.41 \pm 16.76 \mathrm{aA}$ & $73.57 \pm 15.18 \mathrm{bB}$ & 104.49 & $12.58 \pm 0.63 \mathrm{aB}$ & $11.53 \pm 0.68 \mathrm{aC}$ & 12.05 \\
\hline $\mathrm{Si}$ & $100.08 \pm 9.88 \mathrm{aB}$ & $65.33 \pm 9.35 \mathrm{bC}$ & 82.71 & $10.75 \pm 0.44 \mathrm{aB}$ & $12.90 \pm 0.75 \mathrm{aB}$ & 11.83 \\
\hline Control & $96.04 \pm 2.32 \mathrm{bB}$ & $106.39 \pm 3.73 \mathrm{aA}$ & 101.21 & $11.63 \pm 1.09 \mathrm{bC}$ & $15.80 \pm 1.25 \mathrm{aA}$ & 13.71 \\
\hline Average & 108.37 & 84.64 & & 12.58 & 13.41 & \\
\hline Std. dev. & 18.19 & 18.64 & & 2.00 & 1.78 & \\
\hline $\mathrm{CV}$ & $16.79 \%$ & $22.03 \%$ & & $15.89 \%$ & $13.29 \%$ & \\
\hline
\end{tabular}

* Average values followed by the same lowercase letter in the row and by the same uppercase letter in the column do not differ statistically among them, according to Tukey's HSD test at 5\%.

Table 3. Dry weight, leaf area and plant height of the soybean plants for the different seed coating treatments 20 days after emergence. All values are in average \pm standard deviation.

\begin{tabular}{llll}
\hline \multirow{2}{*}{ Nutrient combinations } & \multicolumn{3}{l}{ Dry weight $(\mathrm{g})$} \\
\cline { 2 - 4 } & BRS 243 RR & CD 233 RR & Average \\
\hline $\mathrm{Ca}+\mathrm{Mg}+\mathrm{Si}$ & $1.30 \pm 0.27 \mathrm{aB}$ & $1.21 \pm 0.09 \mathrm{aB}$ & 1.25 \\
$\mathrm{Ca}+\mathrm{Mg}$ & $1.65 \pm 0.12 \mathrm{aB}$ & $1.48 \pm 0.32 \mathrm{aB}$ & 1.56 \\
$\mathrm{Si}$ & $1.53 \pm 0.23 \mathrm{aB}$ & $1.32 \pm 0.10 \mathrm{aB}$ & 1.43 \\
Control & $2.23 \pm 0.51 \mathrm{aA}$ & $2.33 \pm 0.18 \mathrm{aA}$ & 2.28 \\
Average & 1.68 & 1.58 & \\
Std. dev. & 0.39 & 0.51 & \\
$\mathrm{CV}$ & $23.50 \%$ & $32.09 \%$ & \\
\hline
\end{tabular}

\begin{tabular}{lllllll}
\hline \multirow{2}{*}{ Nutrient combinations } & \multicolumn{2}{l}{ Leaf area $\left(\mathrm{cm}^{2}\right)$} & \multicolumn{3}{l}{ Plant height $(\mathrm{cm})$} \\
\cline { 2 - 7 } & BRS 243 RR & CD 233 RR & Average & BRS 243 RR & CD 233 RR & Average \\
\hline $\mathrm{Ca}+\mathrm{Mg}+\mathrm{Si}$ & $556.97 \pm 28.88 \mathrm{aA}$ & $341.06 \pm 35.68 \mathrm{bA}$ & 449.01 & $27.88 \pm 1.36 \mathrm{~b}^{\text {ns }}$ & $33.85 \pm 2.11 \mathrm{aA}$ & 30.86 \\
$\mathrm{Ca}+\mathrm{Mg}$ & $353.2 \pm 31.95 \mathrm{aB}$ & $312.05 \pm 49.25 \mathrm{aA}$ & 332.62 & $27.20 \pm 2.37 \mathrm{a}$ & $26.38 \pm 3.28 \mathrm{aB}$ & 26.79 \\
$\mathrm{Si}$ & $393.39 \pm 56.73 \mathrm{aB}$ & $266.58 \pm 49.35 \mathrm{bB}$ & 329.98 & $26.50 \pm 1.17 \mathrm{a}$ & $22.78 \pm 0.69 \mathrm{aC}$ & 24.64 \\
Control & $425.2 \pm 51.26 \mathrm{aB}$ & $394.58 \pm 40.20 \mathrm{bA}$ & 409.89 & $25.48 \pm 1.33 \mathrm{a}$ & $27.60 \pm 1.27 \mathrm{aB}$ & 26.54 \\
Average & 432.19 & 328.57 & & 26.76 & 27.65 & \\
Std. dev. & 88.25 & 53.63 & & 1.03 & 4.61 & \\
$\mathrm{CV}$ & $20.42 \%$ & $16.32 \%$ & $3.83 \%$ & $16.68 \%$ & \\
\hline
\end{tabular}

* Average values followed by the same lowercase letter in the row and by the same uppercase letter in the column do not differ statistically among them, according to Tukey's HSD test at 5\%. 
Effect of the Treatments 30 Days after Emergence

Data from the dry weight of plants 30 DAE (see Table 4) showed that whereas all treatments were detrimental for CD $233 \mathrm{RR}$ (in particular T3), treatment T1 was beneficial for BRS 243 RR cultivar (although T2 and T3 were not).

Regarding the leaf area at $30 \mathrm{DAE}, \mathrm{T} 1$ and $\mathrm{T} 2$ treatments led to a notable increase for both cultivars (27\% for CD 233 RR and 10\% for BRS 243 RR for T1; 26\% and $16 \%$ for T2, for CD $233 \mathrm{RR}$ and BRS $243 \mathrm{RR}$, respectively). On the other hand, T3 treatment led to a decrease, more marked for CD 233 RR cultivar than for BRS 243 RR (37\% vs. 6\%, respectively).

Plant height 30 DAE was also significantly influenced by seed coatings: for CD 233 $\mathrm{RR}$ it was found that $\mathrm{T} 1(\mathrm{Ca}+\mathrm{Mg}+\mathrm{Si})$ led to an enhanced plant height, while $\mathrm{T} 2$ and T3 were detrimental, as it happened 20 DAE. On the other hand, for BRS 243 RR, all treatments were beneficial: T3 led to values $35 \%$ higher than the control, followed by $\mathrm{T} 1$ (14\% higher than the control) and $\mathrm{T} 2$ (12\% higher than the nontreated samples).

Table 4. Dry weight, leaf area and plant height of the soybean plants for the different seed coating treatments 30 days after emergence. All values are in average \pm standard deviation.

\begin{tabular}{|c|c|c|c|}
\hline \multirow{2}{*}{ Nutrient combinations } & \multicolumn{3}{|l|}{ Dry weight $(\mathrm{g})$} \\
\hline & BRS 243 RR & CD 233 RR & Average \\
\hline $\mathrm{Ca}+\mathrm{Mg}+\mathrm{Si}$ & $5.57 \pm 0.28 \mathrm{aA}$ & $4.12 \pm 0.63 \mathrm{aB}$ & 4.85 \\
\hline $\mathrm{Ca}+\mathrm{Mg}$ & $3.80 \pm 0.78 \mathrm{aB}$ & $3.33 \pm 0.36 \mathrm{aB}$ & 3.57 \\
\hline $\mathrm{Si}$ & $3.88 \pm 0.45 \mathrm{aB}$ & $2.61 \pm 0.30 \mathrm{aC}$ & 3.24 \\
\hline Control & $4.65 \pm 0.06 \mathrm{aB}$ & $4.97 \pm 0.66 \mathrm{aA}$ & 4.81 \\
\hline Average & 4.47 & 3.76 & \\
\hline Std. dev. & 0.83 & 1.01 & \\
\hline $\mathrm{CV}$ & $18.48 \%$ & $27.00 \%$ & \\
\hline
\end{tabular}

\begin{tabular}{lllllll}
\hline \multirow{2}{*}{ Nutrient combinations } & \multicolumn{5}{l}{ Leaf area $\left(\mathrm{cm}^{2}\right)$} & \multicolumn{5}{l}{ Plant height $(\mathrm{cm})$} \\
\cline { 2 - 7 } & BRS 243 RR & CD 233 RR & Average & BRS 243 RR & CD 233 RR & Average \\
\hline $\mathrm{Ca}+\mathrm{Mg}+\mathrm{Si}$ & $716.59 \pm 56.31 \mathrm{bA}$ & $855.55 \pm 27.61 \mathrm{aA}$ & 786.07 & $43.30 \pm 4.86 \mathrm{aB}$ & $46.85 \pm 1.60 \mathrm{aA}$ & 45.08 \\
$\mathrm{Ca}+\mathrm{Mg}$ & $756.91 \pm 26.44 \mathrm{bA}$ & $849.35 \pm 25.84 \mathrm{aA}$ & 803.13 & $42.50 \pm 0.75 \mathrm{aB}$ & $36.98 \pm 1.18 \mathrm{bC}$ & 39.74 \\
$\mathrm{Si}$ & $613.58 \pm 67.46 \mathrm{aB}$ & $418.99 \pm 19.34 \mathrm{bC}$ & 516.28 & $51.30 \pm 0.91 \mathrm{aA}$ & $39.00 \pm 3.03 \mathrm{bB}$ & 45.15 \\
Control & $651.92 \pm 49.95 \mathrm{aB}$ & $672.33 \pm 34.22 \mathrm{aB}$ & 662.12 & $37.93 \pm 1.88 \mathrm{bB}$ & $42.10 \pm 1.15 \mathrm{a} \mathrm{B}$ & 40.01 \\
Average & 684.75 & 699.05 & & 43.76 & 41.23 & \\
Std. dev. & 64.20 & 205.13 & 5.56 & 4.30 & \\
$\mathrm{CV}$ & $9.38 \%$ & $29.34 \%$ & & $12.70 \%$ & $10.42 \%$ & \\
\hline
\end{tabular}

* Average values followed by the same lowercase letter in the row and by the same uppercase letter in the column do not differ statistically among them, according to Tukey's HSD test at 5\%.

\section{Impact of the Treatments on Growth Rates}

As regards the crop growth rate $10 \mathrm{DAE}$ (Table 5), it showed the same behavior discussed for the dry weight 10 DAE.

In relation to the growth rates $20 \mathrm{DAE}$, no significant interactions could be found for the crop growth rate and between the cultivars for the net assimilation rate, only for the relative growth rate. Nevertheless, the three parameters evinced the detrimental impact of the seed coating treatments on both cultivars.

With regard to the results obtained 30 DAE, significant differences between the cultivars were found in terms of the crop growth rate, and BRS 243 RR was superior to CD 233 RR cultivar in all cases (both with and without treatments).It is worth noting that CGR was significantly higher for the seeds coated with T1 treatment for both cultivars. No significant differences were found for the relative growth rate and the net assimilation rate, except for the $\mathrm{T} 1$ treatment: although it had a very limited effect on CD 233 RR cultivar, it had a very positive impact on BRS 243 RR cultivar. 
Table 5. Crop growth rate, relative growth rate and net assimilation rate of the soybean plants -for the different seed coating treatments- 10,20 and 30 days after emergence.

\begin{tabular}{|c|c|c|c|c|c|c|c|c|c|}
\hline \multicolumn{10}{|c|}{ Crop growth rate $\left(\mathrm{mg} \cdot\right.$ plant $^{-1} \cdot$ day $\left.^{-1}\right)$} \\
\hline \multirow{3}{*}{$\begin{array}{l}\text { Nutrient } \\
\text { combinations }\end{array}$} & \multicolumn{3}{|l|}{$10 \mathrm{DAE}$} & \multicolumn{3}{|l|}{$20 \mathrm{DAE}$} & \multicolumn{3}{|l|}{$30 \mathrm{DAE}$} \\
\hline & BRS 243 & 233 & Avo & BRS 243 & CD 233 & & BRS & 233 & \\
\hline & RR & RR & Avg & $\mathrm{RR}$ & RR & Avg. & RR & $\mathrm{RR}$ & Avg. \\
\hline $\mathrm{Ca}+\mathrm{Mg}+\mathrm{Si}$ & $27.80 \mathrm{aA}$ & $22.41 \mathrm{aB}$ & 25.10 & $102.00^{\dagger}$ & $98.72^{\dagger}$ & 100.364 & $427.30 \mathrm{aA}$ & $290.88 \mathrm{bA}$ & 359.09 \\
\hline $\mathrm{Ca}+\mathrm{Mg}$ & $28.88 \mathrm{aA}$ & $24.88 \mathrm{aB}$ & 26.88 & 136.20 & 122.68 & 129.442 & $214.55 \mathrm{aC}$ & $185.85 \mathrm{bC}$ & 200.20 \\
\hline $\mathrm{Si}$ & $27.23 \mathrm{aA}$ & $14.90 \mathrm{bC}$ & 21.06 & 126.13 & 116.88 & 121.502 & $234.43 \mathrm{aC}$ & $129.15 \mathrm{bD}$ & 181.79 \\
\hline Control & $13.58 \mathrm{bB}$ & $33.80 \mathrm{aA}$ & 23.69 & 208.98 & 198.93 & 203.952 & $242.80 \mathrm{aB}$ & $263.80 \mathrm{aB}$ & 253.30 \\
\hline Average & 24.37 & 24.00 & & 143.33 & 134.30 & & 279.77 & 217.42 & \\
\hline Std. dev. & 7.23 & 7.79 & & 46.06 & 44.28 & & 99.07 & 73.79 & \\
\hline \multicolumn{10}{|c|}{ Relative growth rate $\left(\mathrm{mg} \cdot\right.$ plant $^{-1} \cdot$ day $\left.^{-1}\right)$} \\
\hline \multirow{3}{*}{$\begin{array}{l}\text { Nutrient } \\
\text { combinations }\end{array}$} & \multicolumn{3}{|c|}{$10 \mathrm{DAE}$} & \multicolumn{3}{|l|}{$20 \mathrm{DAE}$} & \multicolumn{3}{|l|}{$30 \mathrm{DAE}$} \\
\hline & BRS & $43 \mathrm{CD}$ & 3 Avo & BRS & $3 \mathrm{CD}$ & 233 & $\begin{array}{ll}\text { BRS } & 243\end{array}$ & $3 \mathrm{CD}$ & 3 Avg \\
\hline & $\mathrm{RR}$ & $\mathrm{RR}$ & Avg. & $\mathrm{RR}$ & $\mathrm{RR}$ & $1800^{\circ}$ & $\mathrm{RR}$ & $\mathrm{RR}$ & Avg. \\
\hline $\mathrm{Ca}+\mathrm{Mg}+\mathrm{Si}$ & - & - & - & $0.15 \mathrm{aB}$ & $0.17 \mathrm{aB}$ & 0.16 & $0.15^{\dagger} \mathrm{A}$ & $0.12^{\dagger} \mathrm{A}$ & 0.13 \\
\hline $\mathrm{Ca}+\mathrm{Mg}$ & - & - & - & $0.17 \mathrm{aB}$ & $0.18 \mathrm{aB}$ & 0.18 & $0.08 \mathrm{~B}$ & $0.08 \mathrm{~B}$ & 0.08 \\
\hline $\mathrm{Si}$ & - & - & - & $0.17 \mathrm{aB}$ & $0.22 \mathrm{aA}$ & 0.20 & $0.09 \mathrm{~B}$ & $0.07 \mathrm{~B}$ & 0.08 \\
\hline Control & - & - & - & $0.28 \mathrm{aA}$ & $0.19 \mathrm{bB}$ & 0.24 & $0.07 \mathrm{~B}$ & $0.08 \mathrm{~B}$ & 0.07 \\
\hline Average & - & - & & 0.20 & 0.19 & & 0.10 & 0.09 & \\
\hline Std. dev. & - & - & & 0.06 & 0.02 & & 0.03 & 0.02 & \\
\hline
\end{tabular}

\begin{tabular}{|c|c|c|c|c|c|c|c|c|c|}
\hline \multicolumn{10}{|c|}{ Net assimilation rate $\left(\mathrm{mg} \cdot \mathrm{cm}^{-2} \cdot \mathrm{day}^{-1}\right)$} \\
\hline \multirow{2}{*}{$\begin{array}{l}\text { Nutrient } \\
\text { combinations }\end{array}$} & \multicolumn{3}{|l|}{$10 \mathrm{DAE}$} & \multicolumn{3}{|l|}{$20 \mathrm{DAE}$} & \multicolumn{3}{|l|}{$30 \mathrm{DAE}$} \\
\hline & BRS 243 RR & $\begin{array}{ll}\text { CD } & 233 \\
\text { RR } & \end{array}$ & Avg. & BRS 243 RR & $\begin{array}{l}\text { CD } 233 \\
\text { RR }\end{array}$ & Avg. & BRS 243 RR & $\begin{array}{l}\text { CD } 233 \\
\text { RR }\end{array}$ & Avg. \\
\hline $\mathrm{Ca}+\mathrm{Mg}+\mathrm{Si}$ & - & - & - & $0.38^{\dagger} \mathrm{C}$ & $0.52^{\dagger} \mathrm{B}$ & 0.45 & $0.67^{\dagger} \mathrm{A}$ & $0.52^{\dagger} \mathrm{A}$ & 0.60 \\
\hline $\mathrm{Ca}+\mathrm{Mg}$ & - & - & - & $0.60 \mathrm{~B}$ & $0.74 \mathrm{C}$ & 0.67 & $0.41 \mathrm{~B}$ & $0.35 \mathrm{~B}$ & 0.38 \\
\hline $\mathrm{Si}$ & - & - & - & $0.59 \mathrm{~B}$ & $0.82 \mathrm{~A}$ & 0.70 & $0.47 \mathrm{~B}$ & $0.38 \mathrm{~B}$ & 0.43 \\
\hline Control & - & - & - & $0.94 \mathrm{~A}$ & $0.90 \mathrm{~A}$ & 0.92 & $0.46 \mathrm{~B}$ & $0.51 \mathrm{~A}$ & 0.48 \\
\hline Average & - & - & & 0.63 & 0.75 & & 0.50 & 0.44 & \\
\hline Std. dev. & - & - & & 0.23 & 0.17 & & 0.12 & 0.09 & \\
\hline
\end{tabular}

* Average values followed by the same lowercase letter in the row and by the same uppercase letter in the column do not differ statistically among them, according to Tukey's HSD test at 5\%.

${ }^{\dagger}$ There was no significant interaction among the factors.

In short, significant differences in the response to the treatments were found between the two cultivars. For CD 233 RR, the three treatments under study had -in general terms- a negative impact in the three assessment periods. However, T1 had a positive effect on two particular plant parameters: on plant height (20 DAE and 30 DAE) and on leaf area (30 DAE). On the other hand, all treatments were shown to be beneficial to BRS $243 \mathrm{RR}$ cultivar $10 \mathrm{DAE}$. In subsequent assessment periods (20 DAE and 30 DAE), the effect of T2 and T3 on some plant variables was neutral or negative, but T1 generally had a positive impact (except on the weight $20 \mathrm{DAE}$ ), which was particularly noticeable on LA (20 DAE), SDW, CGR and RGR parameters $(30 \mathrm{DAE})$. These results suggest that $\mathrm{T} 1$ treatment $(\mathrm{Ca}+\mathrm{Mg}+\mathrm{Si})$ would be the best among those under study and could be a promising approach to enhance crop productivity. 


\section{DISCUSSION}

There is a certain degree of controversy concerning the effect of these treatments in the literature. For example, in the work by Castro and Crusciol ${ }^{26}$, when using dolomitic limestone and calcium and magnesium silicate for soil correction, the results evinced that the dry weight of the soybean plants studied 45 DAE was higher when silicate was applied in comparison with limestone, and both treatments led to better results than the control. Similarly, the study by Pereira Júnior, Rezende ${ }^{27}$ on the response of soybean to different doses of silicon found a positive response for plant height and number of pods per plant with increasing doses. Conversely, Oliveira ${ }^{28}$ reported that the application of silicon in the nutrients solution to soybean plants did not have a significant effect on dry matter production 30, 45 and 60 days after emergency.

Silicon absorption by soybean plants is highly variable and may in some cases do not show effects on the analyzed variables, because such effects may be associated to more internal features of the plants, for example to the growth of the cell wall or to the resistance to pests and diseases and to biotic and abiotic stress factors. In this sense, the application of silicon along with calcium and magnesium has nutritional factors that are crucial to the good performance of the plants in the field.

While the influence of silicon in the development soybean is still unclear, as noted above, it is not the case with the Gramineae: according to Raij and Camargo ${ }^{29}$, positive results are commonly observed in plants which accumulate silicon upon its application, as it occurs with most Poaceae (rice, sugarcane, sorghum, wheat, maize, etc.). In the case of rice plants, silicon supplements lead to more efficient photosynthesis and to an increased translocation of carbon to the young parts of the plant ${ }^{30}$, resulting in higher dry matter accumulation. Mauad, Grassi Filho ${ }^{31}$ also showed the fertilization efficiency of silicon in rice plants, confirming an intense and growing accumulation of silicon up to 20 days after emergence (DAE), keeping a steadily growing trend until $75 \mathrm{DAE}$, when the accumulation stabilized. Nonetheless, dry matter accumulation, grain yields and $\mathrm{N}$ contents in the plant were not influenced by the silicon doses. Zanão Júnior, Rodrigues ${ }^{32}$ showed that the application of $\mathrm{Si}$ also has the potential to reduce the development of brown spot, since the high Si content on rice tissue has a negative impact on fungus penetration.

Gong, Chen ${ }^{33}$ reported that plants of wheat growing in pots to which silicon was applied before sowing had greater plant height, leaf area, and dry matter compared to the control in good watering conditions. This is in line with the findings of Souza, Martins ${ }^{34}$, who -while working with different doses of calcium silicate and magnesium and maize plants- found an increase in the dry matter of the aerial part, in leaf area and in height (14 days after sowing) as the silicate dose was increased. It improved the speed of emergence and the early growth of corn seedlings too. Other studies conclude that low magnesium levels lead to less production of dry matter in the case of sorghum ${ }^{35}$ and that calcium deficit limits the growth of the root system of millet and cotton ${ }^{36}$.

In fodder grasses, the main agronomic traits such as plant height may also be influenced by the application of different sources of silicon: Sávio, da Silva ${ }^{37}$ showed that silicon sprayed on leaves promoted an increase in dry biomass content in the second and third harvests of P. maximum.

As regards sunflower, Carvalho, Zanão Júnior ${ }^{38}$ reported that the application of silicon doses did not influence the plant height or stem diameter, but Kamenidou, Cavins ${ }^{39}$ found that the application of silicon actually increased the plant height and stem diameter of the ornamental sunflower "Ring of Fire". In a similar fashion, Gunes, Pilbeam ${ }^{40}$ noted that silicon alleviated drought stress and led to an increase in dry matter production of the aerial part. 
According to Fernandez, Bull ${ }^{41}$, the dry mass of the aerial parts of bean plants was favored by the application of calcium silicate, and doses ranging from 2.31 to 6.95 $\mathrm{g} / \mathrm{pot}$ were associated to the highest efficiency. Divergent results were reported by de Albuquerque Lima, de Castro ${ }^{42}$, who observed that silicon application in the nutrient solution significantly increased all growth parameters (dry weight of leaves, stems and roots and leaf area) and decreased ion leakage in maize seedlings, whereas this response was not observed in cowpea. When foliar supply was tested, it had no impact on any of the two crops.

In relation to the comparison between two cultivars, it is a common approach in experiments that evaluate the performance of seeds subjected to a treatment with nutrients. Several surveys have been conducted in this way, assessing several varieties and their responses to the application of nutrients -such as the works by Tavares et al. with barley seeds ${ }^{43}$ and rice ${ }^{44}$, the one by Ohse, Cubis ${ }^{45}$ with wheat seeds or that by Queiroga, de Queiroz Castro ${ }^{46}$ with cotton seeds, to name a fewand significant differences between cultivars were also found, as in the study reported herein.

\section{CONCLUSIONS}

Three combinations of nutrients $(\mathrm{Ca}+\mathrm{Mg}+\mathrm{Si}, \mathrm{Ca}+\mathrm{Mg}, \mathrm{Si})$ were assayed on two soybean cultivars, namely BRS 243 RR and CD 233 RR, with a view to improving crop productivity in soil acidity conditions. Upon evaluation of different parameters (dry weight, leaf area, plant height and various growth rates), major differences between the response of the two cultivars and amongst the effect of the application in different time periods (10, 20 and $30 \mathrm{DAE})$ were found. It could be concluded that only the application of the $\mathrm{Ca}+\mathrm{Mg}+\mathrm{Si}$ treatment -using dolomitic limestone and aluminum silicate as nutrient sources- would be advisable for the BRS 243 RR cultivar, leading to a very remarkable increase in the crop growth $(76 \%)$, relative growth (97\%) and net assimilation (47\%) rates in the 21-30 DAE emergence period.

\section{ACKNOWLEDGMENTS}

C.A.R and J.F.V. would like to gratefully acknowledge the financial support of CAPES scholarship program and of the Post-Graduate Program in Science and Seed Technology/UFPel.

\section{REFERENCES}

1. Soares MM, Sediyama T, Neves JCL, Santos Júnior HCd, Silva LJd. Nodulation, Growth and Soybean Yield in Response to Seed Coating and Split Application of Phosphorus. Journal of Seed Science. 2016; 38(1): 30-40.

2. Soares MM, Araujo EF, Oliveira GL, da Silva LJ, Soriano PE. Nodulation and growth of soybean plants as a function of coating the seeds with phosphorous. Bioscience Journal. 2014; 30(5): 1438-46.

3. Tavares LC, Tunes LMd, Brunes AP, Fonseca DÂR, Rufino CdA, Barros ACSA, et al. Potassium via coating of soybean seeds: effects on physiological quality and yield. Ciência Rural. 2013; 43(7): 1196-202.

4. Adhikari T, Kundu S, Rao AS. Zinc delivery to plants through seed coating with nano-zinc oxide particles. J Plant Nutr. 2016; 39(1): 139-49.

5. Avelar SAG, Baudet L, de Oliveira S, Ludwig MP, Crizel RL, Rigo GA. Soybean seed treatment and coating with liquid and powdered polymer. Interciencia. 2015; 40(2): 133-7.

6. Hara Y. Improvement of Soybean Seedling Establishment under a Flooded Condition by Seed Coating with Molybdenum Compounds. Plant Production Science. 2015; 18(2): 161-5. 
7. Coutinho ELM, Natale W, Souza ECAd, Ferreira ME, Castellane PD, Cruz MCP, editors. Adubos e corretivos: aspectos particulares na olericultura. Simpósio sobre nutrição e adubação de hortaliças; 1993; Piracicaba, Sao Paulo, Brazil: Potafos.

8. Quaggio JA. Acidez e calagem em solos tropicais. Campinas, SP, Brazil: Instituto Agronômico (IAC); 2000. 111 p.

9. Nolla A, Anghinoni I. Métodos utilizados para a correção da acidez do solo no Brasil. RECEN-Revista Ciências Exatas e Naturais. 2009; 6(1): 97-111.

10. de Sousa DMG, Lobato E. Cerrado: correção do solo e adubação. $2^{\text {nd }}$ ed. Brasilia, Brazil: EMBRAPA; 2004. 416 p.

11. Orlando Filho J, Bittencourt VC, Carmello QAC, Beauclair EGF. Relações K, Ca e Mg de solo areia quartzosa e produtividade da cana-de-açúcar. Stab, Açúcar Álcool e Subprodutos. 1996; 14(5).

12. Ma JF, Miyake Y, Takahashi E. Silicon as a beneficial element for crop plants. Studies in plant Science. 2001; 8: 17-39.

13. Ma JF. Role of silicon in enhancing the resistance of plants to biotic and abiotic stresses. Soil Sci Plant Nutr. 2004; 50(1): 11-8.

14. Aprova o Regulamento da Lei $\mathrm{n}^{\circ}$ 6.894, de 16 de dezembro de 1980, que dispõe sobre a inspeção e fiscalização da produção e do comércio de fertilizantes, corretivos, inoculantes ou biofertilizantes destinados à agricultura, e dá outras providências., (2004).

15. Epstein E. The anomaly of silicon in plant biology. Proceedings of the National Academy of Sciences. 1994; 91(1): 11-7.

16. Marschner H. Mineral nutrition of higher plants. $3^{\text {rd }}$ ed. Cambridge, MA, USA: Academic Press; 2011. 672 p.

17. Santos GR, Korndorfer GH, Filho JCDR, Pelúzio JM. Adubação com silício: Influência sobre as principais doenças e sobre produtividade do arroz irrigado por inundação. Revista Ceres. 2003; 50: 1-8.

18. Pereira HS, Korndörfer GH, Vidal AA, Camargo MSd. Fontes de silício para a cultura do arroz. Scientia Agricola. 2004; 61(5): 522-8.

19. Date RA, Grundon NJ, Rayment GE, Probert ME, editors. Plant-Soil Interactions at Low $\mathrm{pH}$ : Principles and Management. Third International Symposium on Plant-Soil Interactions at Low pH; 1995 12-16 September 1993; Brisbane, Queensland, Australia: Springer Science \& Business Media, BV.

20. Bacanamwo M, Purcell LC. Soybean dry matter and $\mathrm{N}$ accumulation responses to flooding stress, N sources and hypoxia. J Exp Bot. 1999; 50(334): 689-96.

21. Nunes JC. Tratamento de semente-qualidade e fatores que podem afetar a sua performance em laboratório. Londrina: Syngenta Proteção de Cultivos Ltda. 2005.

22. EMBRAPA. Sistema brasileiro de classificação de solos. Rio de Janeiro, Brazil: Empresa Brasileira de Pesquisa Agropecuária; 2006.

23. CQFS-RS/SC. Manual de Adubação e de Calagem para os estados do Rio Grande do Sul e de Santa Catarina. 10th ed. Porto Alegre, Brazil: Comissão de Química e Fertilidade do Solo (CQFS RS/SC); 2004. 400 p.

24. Gardner FP, Pearce RB, Mitchell RL. Physiology of crop plants. 1st ed. Ames: Iowa State University Press; 1985. viii, 327 p. p.

25. Machado AA, Conceição AR. WinStat - Sistema de Análise Estatística para Windows. 2.0 ed. Rio Grande do Sul, Brazil: Universidade Federal de Pelotas; 2007.

26. Castro GSA, Crusciol CAC. Effects of surface application of dolomitic limestone and calcium-magnesium silicate on soybean and maize in rotation with green manure in a tropical region. Bragantia. 2015; 74(3): 311-21.

27. Pereira Júnior P, Rezende PM, Malfitano SC, Lima RK, Corrêa LVT, Carvalho ER. Efeito de doses de silício sobre a produtividade e características agronômicas da soja [Glycine max (L.) Merrill]. Ciência e Agrotecnologia. 2010; 34(4): 908-13.

28. Oliveira AL. Silício em plantas de feijão e arroz: absorção, transporte, redistribuição e tolerância ao Cadmio. Piracicaba, Brazil: Universidade de São Paulo; 2009.

29. Raij Bv, Camargo OA. Sílica solúvel em solos. Bragantia. 1973; 32: 223-36.

30. Korndörfer GH, Arantes VA, Corrêa GF, Snyder GH. Efeito do silicato de cálcio no teor de silício no solo e na produção de grãos de arroz de sequeiro. Revista Brasileira de Ciência do Solo. 1999; 23(3): 635-41. 
31. Mauad M, Grassi Filho H, Crusciol CAC, Corrêa JC. Teores de silício no solo e na planta de arroz de terras altas com diferentes doses de adubação silicatada e nitrogenada. Revista Brasileira de Ciência do Solo. 2003; 27(5): 867-73.

32. Zanão Júnior LA, Rodrigues Fabrício Á, Fontes RLF, Korndörfer GH, Neves JCL. Rice Resistance to Brown Spot Mediated by Silicon and its Interaction with Manganese. $J$ Phytopathol. 2009; 157(2): 73-8.

33. Gong HJ, Chen KM, Chen GC, Wang SM, Zhang CL. Effects of silicon on growth of wheat under drought. J Plant Nutr. 2003; 26(5): 1055-63.

34. Souza JPF, Martins GLM, Pereira AC, Binotti FFdS, Maruyama WI. Efeito de silicato de cálcio e magnésio no crescimento inicial de milho transgênico. Revista de Agricultura Neotropical. 2015; 2(3): 13-7.

35. Tan K, Keltjens WG. Analysis of acid-soil stress in sorghum genotypes with emphasis on aluminium and magnesium interactions. Plant Soil. 1995; 171(1): 147-50.

36. do Vale FR, Neto AEF, Renó NB, Fernandes LA, Resende AV. Crescimento radicular de espécies florestais em solo ácido. Pesquisa agropecuária brasileira. 1996; 31(9): 609-16.

37. Sávio FL, da Silva GC, Teixeira IR, Borém A. Produção de biomassa e conteúdo de silício em gramíneas forrageiras sob diferentes fontes de silicato. Semina: Ciências Agrárias. 2011; 32(1): 103-10.

38. Carvalho MP, Zanão Júnior LA, Grossi JAS, Barbosa JG. Silício melhora produção e qualidade do girassol ornamental em vaso. Ciência Rural. 2009; 39(8): 2394-9.

39. Kamenidou S, Cavins TJ, Marek S. Silicon supplements affect horticultural traits of greenhouse-produced ornamental sunflowers. HortScience. 2008; 43(1): 236-9.

40. Gunes A, Pilbeam DJ, Inal A, Coban S. Influence of Silicon on Sunflower Cultivars under Drought Stress, I: Growth, Antioxidant Mechanisms, and Lipid Peroxidation. Commun Soil Sci Plant Anal. 2008; 39(13-14): 1885-903.

41. Fernandez FA, Bull LT, Corrêa JC, Crespam DR. Influência de silicato e calcário na decomposição de resíduos culturais e disponibilidade de nutrientes ao feijoeiro. Revista Brasileira de Ciência do Solo. 2009; 33(4): 935-45.

42. de Albuquerque Lima M, de Castro VF, Vidal JB, Enéas-Filho J. Aplicação de silício em milho e feijão-de-corda sob estresse salino. Revista Ciência Agronômica. 2011; 42(2): 398403.

43. Tavares LC, Brunes AP, Rufino CDA, Fonseca DARd, Gadotti GI, Villela FA. Tratamento de sementes de cevada com zinco: potencial fisiológico e produtividade de sementes. Semina: Ciências Agrárias. 2015; 36(2): 585.

44. Tavares LC, Fonseca DÂR, Brunes AP, Rufino CdA, Meneguello GE, Barros ACSA. Performance of rice seeds treated with zinc, boron, and molybdenum. Journal of Seed Science. 2013; 35(4): 532-9.

45. Ohse S, Cubis JG, Rezende BLA, Gonçalves Cortez M, Otto RF. Vigor e viabilidade de sementes de trigo tratadas com zinco. Biotemas. 2012; 25(4).

46. Queiroga VdP, de Queiroz Castro LB, Palmeira Gomes J, da Silva AL, Cezar Alves NM, Ribeiro de Araujo D. Qualidade fisiológica de sementes de algodão armazenadas em função de diferentes tratamentos e cultivares. Revista Brasileira de Produtos Agroindustriais. 2009; 11(1): 43-54. 